\title{
Indol-2-ylidene (IdY): A New Ambiphilic N-heterocyclic Carbene Derived from Indole
}

\author{
Hyunho Kim, ${ }^{[a]}$ Minseop Kim, ${ }^{[a]}$ Hayoung Song, ${ }^{*}$ [a] and Eunsung Lee ${ }^{*}$ [a]
}

\author{
[a] H. Kim, M. Kim, Dr. H. Song, Prof. E. Lee \\ Department of Chemistry \\ Pohang University of Science and Technology \\ Pohang, 790-784, Republic of Korea \\ E-mail: shy0714@postech.ac.kr, eslee@postech.ac.kr \\ Supporting information for this article is given via a link at the end of the document
}

\begin{abstract}
The ambiphilic N-heterocyclic carbene ligand, indol-2ylidene (IdY, A), is described. A series of indolenium precursors (2af) were prepared on a gram scale in good yields. Trapping experiments with elemental selenium, $[\mathrm{RhCl}(\mathrm{cod})]_{2}$ and $\mathrm{CuCl}$ lead to IdY-supported materials, respectively. Computational and spectroscopic studies revealed the ambiphilicity of IdY. The copper complexes $(6)$ show high percent buried volume $\left(\% \mathrm{~V}_{\text {bur }}=58.1\right)$ and allow for carboboration of terminal alkynes within 30 minutes as synthetically useful yields and high regioselectivity.
\end{abstract}

The N-heterocyclic carbenes (NHCs) have been widely used in transition metal catalysis, ${ }^{[1]}$ nanoparticle stabilization, ${ }^{[2]}$ organocatalysis, ${ }^{[3]}$ and main group chemistry ${ }^{[4]}$ for three decades. One of the representative $\mathrm{NHC}$ scaffolds is imidazol-2-ylidene derived from imidazole - an abundant motif in natural products ${ }^{[5]}$ and drug molecules. ${ }^{[6]}$ Derivatization of the imidazole scaffold has been studied extensively and the synthetic studies ${ }^{[7]}$ paved the way to development of new types of NHCs such as asymmetric $\mathrm{NHCs}^{[8]}$, unsymmetric $\mathrm{NHCs}^{\left[{ }^{[9]}\right.}$ and hemilabile NHCs. ${ }^{[10]}$

Cyclic (alkyl)(amino)carbenes (CAACs) are also receiving remarkable attention because of their ambiphilic properties. ${ }^{[11]}$ Structural modification by replacement of nitrogen group ( $\pi$-electron donating, $\sigma$-withdrawing) to alkyl group ( $\sigma$-donating) makes carbene more electrophilic but also nucleophilic. In addition, the small HOMO-LUMO energy gap facilitates the smaller singlet-triplet (S/T) gap and it is an important factor in the context of reactivity of NHCs towards inert small molecules such as carbon monoxide. ${ }^{[12]}$ Thanks to the ambiphilicity, CAAC ligands have been applied in diverse fields such as light emitting materials as CAAC-Cu complexes ${ }^{[13]}$ and novel transition metal catalysis. ${ }^{[14]}$ Furthermore, isolated CAACs were used for stabilization of paramagnetic species ${ }^{[4 \mathrm{~b}, 15]}$ and activation of small molecules or enthalpically strong bonds. ${ }^{[16]}$<smiles>CC1(C)c2ccccc2CN1P</smiles>

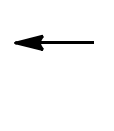<smiles>CN1CC2CC3CCCC2C31</smiles>

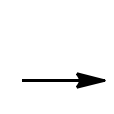

R

CAAC-5

CAArC (Bertrand)

CAAC

(Bertrand)<smiles>[R]N1CC(C)(C)c2ccccc21</smiles>

IdY

- Ambiphilic N-heterocyclic carbene

- Facile preparation \& Gram scale synthesis

- Catalytic activity - Fast $\&$ High regioselective carboboration

Figure 1. Strategies for increasing ambiphilicity of CAACs

Following the pioneering work on CAACs, other classes of ambiphilic NHCs have been developed. Ambiphilicity increased by structural modification strategies, such as replacement of amino group by amido group ${ }^{[17 a, b, f, j, k]}$ or aryl group ${ }^{[17 e, ~ h, ~ j, ~ k] ~}$. Controlling the ring property also increased the ambiphilicity ${ }^{[17 c, d}$, g, i]. These ambiphilic NHCs exhibit unique reactivity such as exchange reactions at main group elements ${ }^{[17 g]}$ and $(2+1)$ cycloaddition with dimethyl maleate or fumarate..$^{[17 k]}$ In the same vein, the in-dole scaffold is a promising candidate for ambiphilic $\mathrm{NHCs}$ due to its cyclic (alkyl)(amino) fragment and presence of an aryl group (Figure 1), in close resemblance to known ambiphilic NHCs. $\left.{ }^{[17 e, ~} \mathrm{h}, \mathrm{j}, \mathrm{k}\right]$ Moreover, because the indole structure is one of the most common $\mathrm{N}$-heterocycles found in drug molecules and natural products ${ }^{[18]}$ numerous synthetic methods ${ }^{[19]}$ for the indole moiety have been reported to date. In this context, it is surprising that indole based NHCs has not yet been developed. In order to fill this research gap we decided to explore the potential of indole derived NHCs and designed 'Indol-2-ylidene (IdY, A)'.

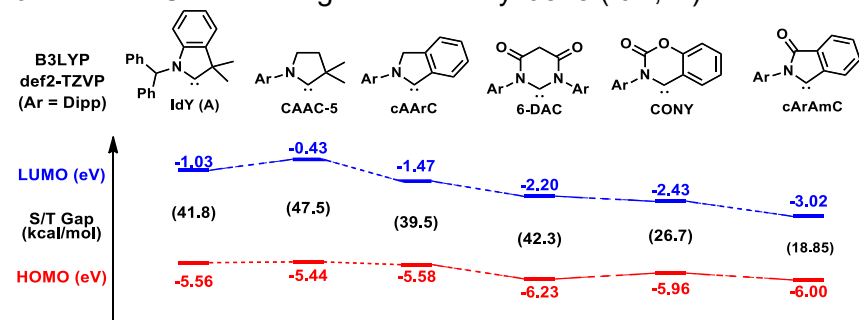

Figure 2. HOMO-LUMO Energy Level (eV) and Singlet-Triplet Transition Energy $(\mathrm{kcal} / \mathrm{mol}$ ) of NHCs Calculated at the B3LYP/def2-TZVP Level of Theory.

We started by performing a computational study to access electronic properties of IdY (A) and compare it with other hitherto reported ambiphilic NHCs (Figure 2). Hence, the HOMO energy level of $\mathrm{A}(-5.56 \mathrm{eV})$ is similar to the HOMO energy level of CAAC$5(-5.44 \mathrm{eV})$, while the LUMO energy level of $\mathbf{A}(-1.03 \mathrm{eV})$ is intermediate between CAAC $-5(-0.43 \mathrm{eV})$ and cAArC $(-1.47 \mathrm{eV})$. Furthermore, the $S / T$ gap of $\mathbf{A}(41.8 \mathrm{kcal} / \mathrm{mol})$ is comparable to the one in $\mathrm{cAArC}(39.5 \mathrm{kcal} / \mathrm{mol})$. The computational results therefore predicted the ambiphilic nature of $\mathbf{A}$. 


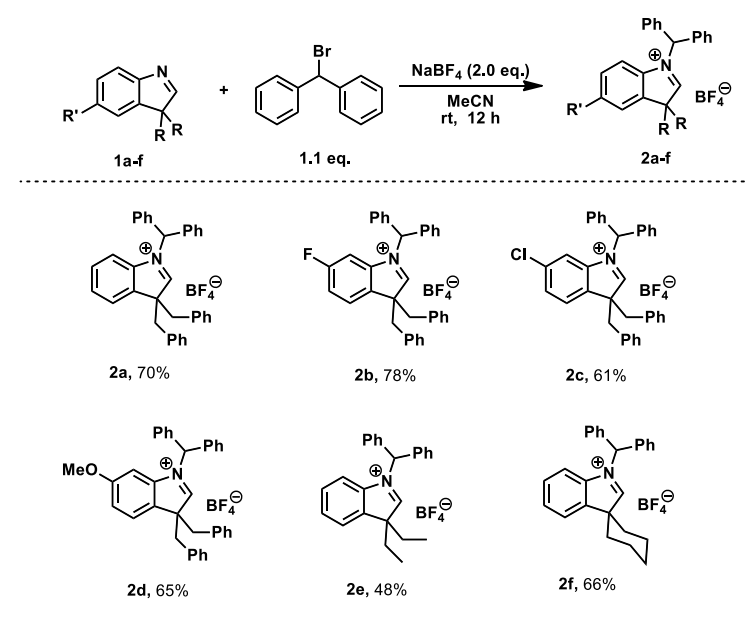

Scheme 1. Synthesis of substituted indolenium precursor (2). 'Bn' is benzyl

After confirming the ambiphilicity of A by computational studies, we proceeded to the synthesis of the indolenium salts (2), expected to provide A (Scheme 1) after deprotonation. Since attempts to introduce the isopropyl group, tBu group and aryl group commonly used for NHC into $\mathbf{1}$ are not accessible, the benzhydryl group was chosen as the sterically bulky alkyl group. The desired indolenium precursors (2a-f) were obtained in a simple two step reaction on a multigram scale in good yields. In the first step, the quaternary indolenine derivatives (1) were prepared following Fischer indole synthesis ${ }^{[19 b]}$ and Yang's indolenine synthesis ${ }^{[19 c]}$ (See SI). For the subsequent alkylation step, the sterically bulky benzhydryl group was chosen. Introduction of a bulky substituent on the nitrogen atom was supposed to improve the stability of $\mathbf{A}$ due to steric protection of the carbene center. ${ }^{[20]}$ Indeed, in the single crystal structure of $\mathbf{2 f}$ the benzhydryl group is effectively shielding the C2 position (See $\mathrm{SI})$. Since the aromatic ring substituent $\mathrm{R}$ can be varied easily, the LUMO energy levels of $\mathbf{A}$ can be tuned in a rational fashion (See SI).<smiles>[R]c1ccc2c(c1)C(Cc1ccccc1)(Cc1ccccc1)C(=[Se])N2Cc1ccccc1</smiles>

$\begin{array}{ccc}\text { Entry } & \text { R } & 77 \text { Se NMR (ppm) } \\ \ldots \text { 3a } & \text { H } & 542 \\ 3 b & \text { F } & 550 \\ 3 c & \text { Cl } & 570^{[\mathrm{a}]} \\ \text { 3d } & \text { OMe } & 508\end{array}$

3

Figure 3. Carbene-selenium Adducts (3) and their ${ }^{77} \mathrm{Se}$ Chemical Shifts (solvent: $\left(\mathrm{CD}_{3}\right)_{2} \mathrm{CO}$ ). 'Bn' is benzyl group. [a]: in $\mathrm{CDCl}_{3}$

With the indolenium precursors (2) in hand, we attempted to generate the free $\mathrm{A}$ by deprotonation at $-78{ }^{\circ} \mathrm{C}$ using various nonnucleophilic bases such as $\mathrm{MN}\left(\mathrm{SiMe}_{3}\right)_{2}(\mathrm{M}=\mathrm{K}, \mathrm{Na}, \mathrm{Li}), \mathrm{MOtBu}$ $(\mathrm{M}=\mathrm{K}, \mathrm{Na}), \mathrm{LDA}$ and $\mathrm{NaH}$. Unfortunately, a complicated mixture of products was obtained in each case, in similarity to cAArCs. Being unable to obtain the free $\mathbf{A}$, we performed trapping experiments with elemental selenium and were pleased to isolate the corresponding IdY-selenium adducts (3 in Figure 3 ). The structures of $\mathbf{3 c}$ and $\mathbf{3 d}$ were clearly confirmed by a single crystal $\mathrm{X}$-ray diffraction analysis (see $\mathrm{SI}$ ). In the solid state structures, non-classical hydrogen bonding $(\mathrm{NCHB})$ between $\mathrm{C}\left(\mathrm{sp}^{3}\right) \mathrm{H}$ and selenium was observed (See SI). ${ }^{[21]}$

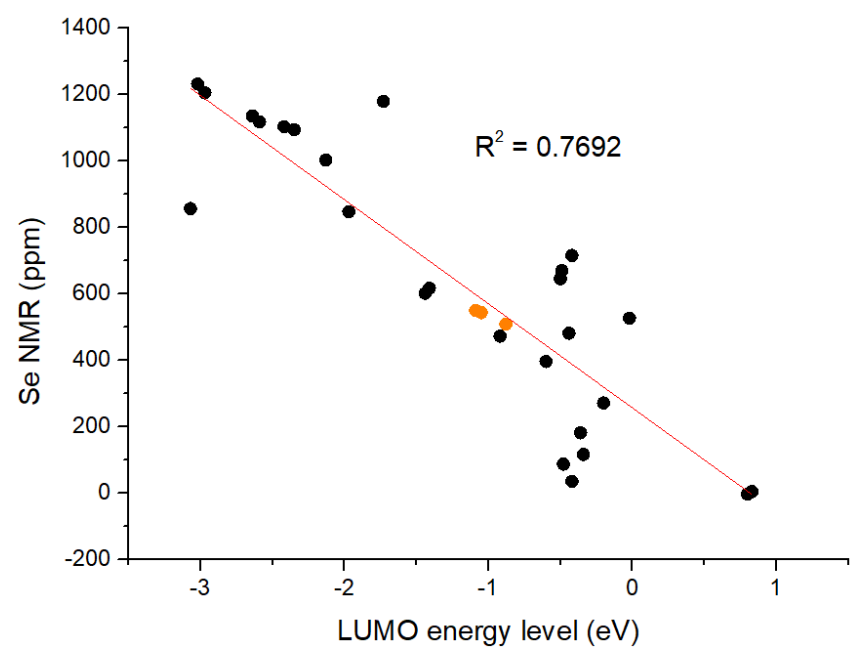

Figure 4. ${ }^{77} \mathrm{Se} N M R$ shifts (ppm, in $\mathrm{d}_{6}$-acetone) of carbene-selenium adducts (data for $\mathbf{3}$ are in orange, all typical carbene-selenium adducts excluding $\mathbf{3}$ are in black) vs LUMO of the free NHCs (calculated at B3LYP/def2-TZVP)

To test the m-accepting properties of $\mathbf{A}$, we measured the ${ }^{77} \mathrm{Se}$ NMR shifts of $\mathbf{3 a}-\mathbf{d}$ and compared them with values obtained for other NHCs as suggested by Ganter. ${ }^{[22]}$ 3a exhibits an intermediate ${ }^{77}$ Se NMR shift (542 ppm) between CAAC-5 (481 ppm) and cAArC (601 ppm), as expected from the trend in LUMO energies (Figure 2). Indeed, plotting the LUMO energy level versus ${ }^{77} \mathrm{Se}$ NMR shifts of 29 analogous ${ }^{[22-23]}$ (Figure 4) provides appropriate linear relation $\left(R^{2}=0.7692\right)$. To explore further, we considered two conformers, $\mathbf{3} \mathbf{a}$ and $\mathbf{3} \mathbf{a}^{\prime}$ (See $\mathrm{SI}$ ), differing in the orientation of the benzhydryl group with respect to the selenium atom. ${ }^{77}$ Se NMR shifts of 498 (3a) and 584 (3a') ppm were predicted (BP86/def2-TZVP) and their average value (541 ppm) is in good agreement with the experimental data (542 ppm). Since $3 \mathbf{a}^{\prime}$ is energetically accessible $(+3.48 \mathrm{kcal} / \mathrm{mol})$ in the solution phase, we suggest that $\mathbf{3 a}$ and $\mathbf{3} \mathbf{a}^{\prime}$ exist in equilibrium in solution and the observed ${ }^{77} \mathrm{Se}$ NMR shift is a result of their rapid exchange. Moreover, the inductive effect of the $\mathrm{R}$ substituent on the aryl backbone was reflected by ${ }^{77} \mathrm{Se}$ NMR shifts, with the most electron deficient $\mathbf{3 c}$ having the highest (570 ppm) and electron rich $\mathbf{3 d}$ the lowest (508 ppm) chemical shift (Figure 3).

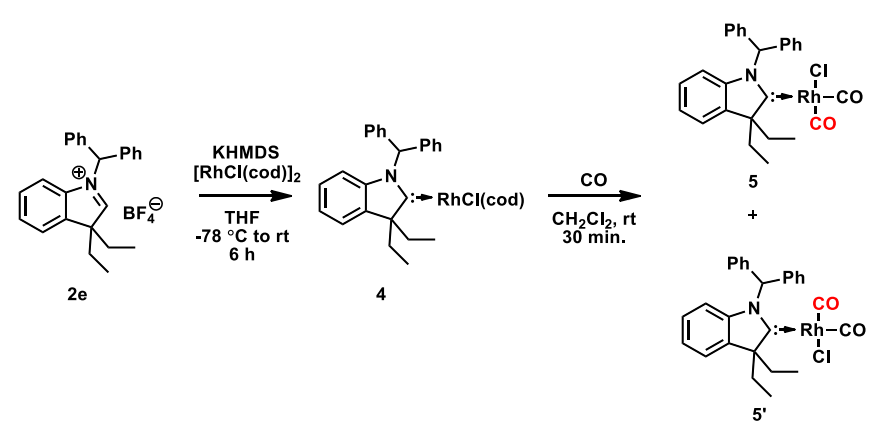

Scheme 2. Synthesis Rhodium Complexes of IdY (4, 5 and 5').

In addition to selenium trapping experiments, we demonstrated the presence of IdY free carbene by formation of IdY-metal complexes. Hence, IdY-Rh complex (4) could be synthesized by metalation of in-situ generated free carbene (Scheme 2). This complex features a highly deshielded carbene-metal ${ }^{13} \mathrm{C}$ NMR peak (4: $276 \mathrm{ppm}\left(\mathrm{J}_{\mathrm{Rh}-\mathrm{C}}=47.4 \mathrm{~Hz}\right)$ in $\mathrm{CDCl}_{3}$ ), in close resemblance to the previously reported CAAC-5-metal 
complexes (CAAC-5-RhCl(cod): $278 \mathrm{ppm}\left(\mathrm{J}_{\mathrm{Rh}-\mathrm{C}}=45.0 \mathrm{~Hz}\right)$ in $\mathrm{CDCl}_{3}$ ). The carbonylation of $\mathbf{4}$ generated inseparable two rotamers $\left(\mathbf{5}, \mathbf{5}^{\prime}\right)$ which exhibited three different IR absorption signals at 1972, 1995 and $2074 \mathrm{~cm}^{-1}$ (ATR). DFT calculations allowed to assign these signals to 1980 and $1989 \mathrm{~cm}^{-1}$ (red, Scheme 2) and $2055 \mathrm{~cm}^{-1}$ (black, Scheme 2, see SI). The average values of the experimental data are $2023 \mathrm{~cm}^{-1}$ and 2035 $\mathrm{cm}^{-1}$, indicating that $\mathbf{A}$ is a strong electron-donating ligand, comparable to CAAC-6 $\left(v^{\text {av }}{ }_{C O}=2029 \mathrm{~cm}^{-1}\right)$ and BICAAC $\left(v^{\mathrm{av}}{ }_{\mathrm{CO}}=\right.$ $2032 \mathrm{~cm}^{-1}$ )
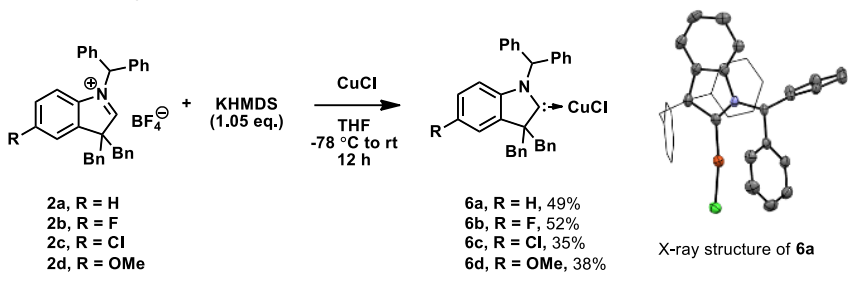

Scheme 3. Synthesis of Copper complexes of IdY (6) and X-ray structure of $6 \mathbf{a}$ 'Bn' is benzyl group

Apart from the rhodium complexes, a series of $\mathrm{IdY}-\mathrm{CuCl}$ complexes 6 was synthesized successfully (Scheme 3). Similar to $\mathbf{4}$ and $\mathbf{5}$, these copper complexes showed highly deshielded carbene-metal peaks (6a: $246 \mathrm{ppm}$ ) in ${ }^{13} \mathrm{C}-\mathrm{NMR}$ spectra, comparable to CAAC-5-CuCl $(250 \mathrm{ppm})^{[24]}$. The complex $6 \mathbf{a}$ could also be characterized by $\mathrm{X}$-ray crystallographic analysis (see $\mathrm{SI}$ ). In the solid state structure, the benzhydryl group effectively shields the copper center.

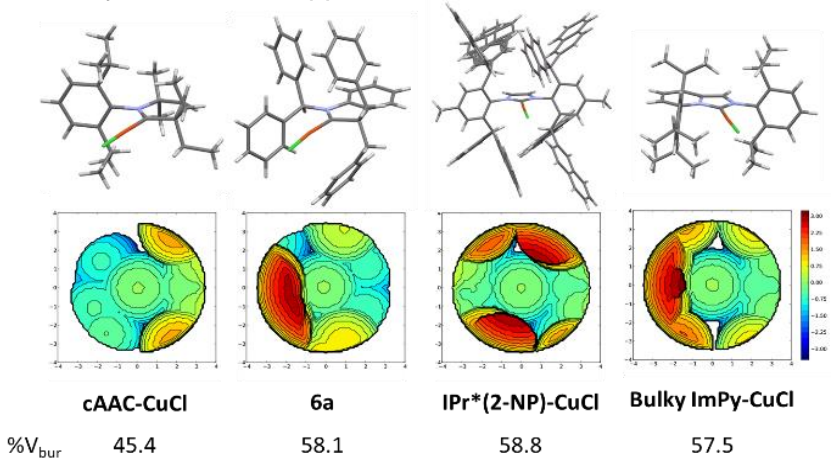

Figure 5. Structure of the CAAC-5-CuCl, ${ }^{[24 b]} 6 \mathbf{a}, \mathrm{IPr}^{*}(2-\mathrm{NP})-\mathrm{CuCl}^{[24 \mathrm{a}]}$ and bulky ImPy-CuCl, ${ }^{[24 c]}$ and their steric maps calculated via SambVca 2.0 with a sphere radius of $3.5 \AA$; a distance from sphere $2.0 \AA$; Mesh step $0.05 \AA$; bondi radii scaled by $1.17 ; \mathrm{H}$ atom omitted.

The observation of the crowded environment around the $\mathrm{Cu}$ center in $\mathbf{6 a}$ in the solid state prompted us to further explore the steric properties of $\mathbf{6 a}$ by percent buried volume calculation $\left(\% \mathrm{~V}_{\text {bur }}\right)$. Hence, we compared the $\% \mathrm{~V}_{\text {bur }}$ of $6 \mathrm{a}$ and previously reported CAAC-5- $\mathrm{CuCl}$ (Figure 5). Due to the benzhydryl group, 6a shows a more crowded environment $\left(\% \mathrm{~V}_{\text {bur }}=58.1\right)$ around the $\mathrm{Cu}$ center than the CAAC-5-CuCl $\left(\% \mathrm{~V}_{\text {bur }}=45.4\right)$. In fact, the $\% \mathrm{~V}_{\text {bur }}$ value of $6 \mathrm{a}$ is similar to the one obtained for NHCs with the largest steric hindrance reported so far $\left(\% \mathrm{~V}_{\text {bur }}=57.5[\mathrm{Bulky}\right.$ $\operatorname{ImPy}-\mathrm{CuCl}])$ and $\left.58.8\left[\mathrm{IPr}^{*}(2-\mathrm{NP})-\mathrm{CuCl}\right]\right)$.

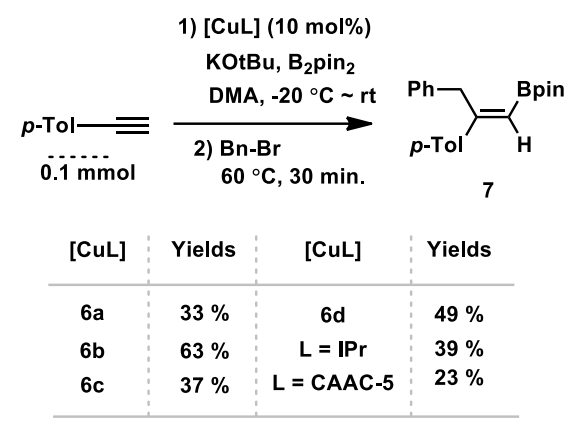

Scheme 4. Catalyst performance in benzylboration of $p$-tolyl acetylene. Yields were determined by NMR analysis with internal standard $\left(\mathrm{CH}_{2} \mathrm{Br}_{2}\right)$.

Having confirmed the ambiphilic nature and considerable steric bulkiness of IdY, we seeked to demonstrate the utility of IdYmetal complexes in organic synthesis. Following the previous work in the field, NHC complexes of large buried volume ${ }^{[25]}$ and strong $\pi$-accepting $\mathrm{NHC}$ ligands ${ }^{[26]}$ find application in regioselective carboboration of alkynes. Inspired by these works, we investigated the benzylboration of $p$-tolyl acetylene in presence of $\mathbf{6}$ as a catalyst. Interestingly, in case of $\mathbf{6 a}$ the reaction was terminated after only 30 minutes with the appropriate yields of $35 \%$. Further optimization (Scheme 4) indicated a superior performance of $\mathbf{6 b}$ compared to the other IdY-CuCl and representative $\mathrm{NHC}-\mathrm{CuCl}$ complexes $(\mathrm{IPr}-\mathrm{CuCl}$ and $\mathrm{CAAC}-5-$ $\mathrm{CuCl})$. After this simple optimization, we chose $\mathbf{6 b}$ as the optimal catalyst and expanded the substrate scope of the alkyne (7-9, Scheme 5). In case of each substrate, synthetically useful yields and high regioselectivity were observed.

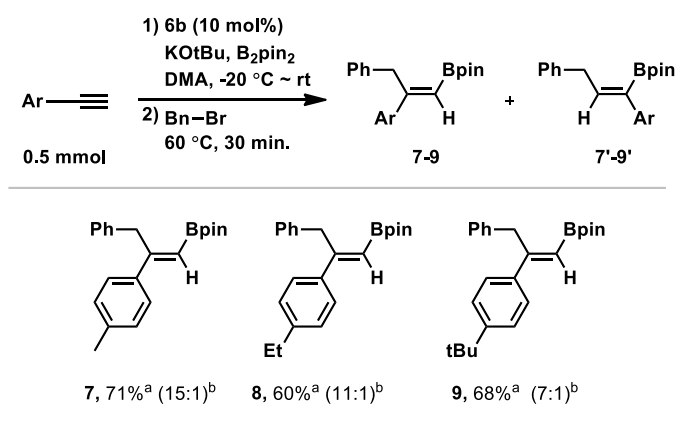

Scheme 5. Substrate scope of benzylboration using $\mathbf{6 b}$ as a catalyst. Yields: isolated yields. ' $\mathrm{Bn}$ ' is benzyl group. a) combined yields, b) ratio of 7-9 and 7'-9'

In summary, we developed a convenient synthesis of indolenium precursors (2) for a new ambiphilic carbene, indol-2-ylidene (IdY, A). The ambiphilicity of $\mathbf{A}$ was demonstrated by computational studies and indirectly by spectroscopic characterization of the corresponding selenium adducts and metal complexes. The IdY$\mathrm{CuCl}$ complexes (6) showed good catalytic activity in a carboboration reaction. Further development of the IdY framework for free carbene are currently underway in our laboratory and will be reported in due course.

\section{Acknowledgements}

This work was financially supported by the National Research Foundation of Korea (NRF-2019R1A2C2010732, NRF2019R1A2C2010732). This work was also supported by Korea 
Toray Science Foundation and the computational resource was supported by KISTI (KSC-2019-CRE-0162). High resolution mass spectrometry was performed at the Korea Basic Science Institute (DS107). We thank to Jeongmin Cha for assistance with FT-IR measurement, Dr. Ewa Pietrasiak, Dr. Youngsuk Kim, Hyungdo Cho, Hyunchul Kwon and Yeosan Lee for helpful discussions.

\section{Conflict of interest}

The authors declare no conflict of interest.

Keywords: N-heterocyclic carbenes - ambiphilic carbenes • ligand design $\bullet$ indole $\cdot$ copper catalysis

[1] a) L. Ackermann, A. Fürstner, T. Weskamp, F. J. Kohl. W. A. Herrmann, Tetrahedron Lett. 1999, 40 4787-4790; b) J. Huang, E. D. Stevens, S. P. Nolan. J. L. Petersen, J. Am. Chem. Soc 1999, 121 2674-2678; c) M. Scholl, S. Ding, C. W. Lee. R. H. Grubbs, Org. Lett. 1999, 1953-956; d) F. E. Hahn. M. C. Jahnke, Angew. Chem. Int. Ed. 2008, 47 3122-3172; e) S. DíezGonzález, N. Marion. S. P. Nolan, Chem. Rev. 2009, 10936123676; f) N. I. Saper. J. F. Hartwig, J. Am. Chem. Soc. 2017, 139 17667-17676; g) H. M. O’Brien, M. Manzotti, R. D. Abrams, D. Elorriaga, H. A. Sparkes, S. A. Davis. R. B. Bedford, Nat. Catal. 2018, 1 429-437; h) T. Chen, H. Yang, Y. Yang, G. Dong. D. Xing, ACS Catal. 2020, 10 4238-4243.

[2] a) A. V. Zhukhovitskiy, M. J. MacLeod. J. A. Johnson, Chem. Rev. 2015, 11511503-11532; b) L. M. Martínez-Prieto, A. Ferry, L. Rakers, C. Richter, P. Lecante, K. Philippot, B. Chaudret. F. Glorius, Chem. Commun. 2016, 52 4768-4771; c) N. Möller, A. Rühling, S. Lamping, T. Hellwig, C. Fallnich, B. J. Ravoo. F. Glorius, Angew. Chem. Int. Ed. 2017, 56 4356-4360; d) K. Salorinne, R. W. Y. Man, C.-H. Li, M. Taki, M. Nambo. C. M. Crudden, Angew. Chem. Int. Ed. 2017, 56 6198-6202; e) R. W. Y. Man, C.-H. Li, M. W. A. MacLean, O. V. Zenkina, M. T. Zamora, L. N. Saunders, A. Rousina-Webb, M. Nambo. C. M Crudden, J. Am. Chem. Soc. 2018, 140 1576-1579; f) R. Ye, A V. Zhukhovitskiy, R. V. Kazantsev, S. C. Fakra, B. B. Wickemeyer, F. D. Toste. G. A. Somorjai, J. Am. Chem. Soc. 2018, 140 4144-4149; g) M. J. MacLeod, A. J. Goodman, H. Z. Ye, H. V. T. Nguyen, T. Van Voorhis. J. A. Johnson, Nat Chem. 2019, 11 57-63; h) M. R. Narouz, K. M. Osten, P. J. Unsworth, R. W. Y. Man, K. Salorinne, S. Takano, R. Tomihara, S. Kaappa, S. Malola, C.-T. Dinh, J. D. Padmos, K. Ayoo, P. J. Garrett, M. Nambo, J. H. Horton, E. H. Sargent, H. Häkkinen, T. Tsukuda. C. M. Crudden, Nat. Chem. 2019, 11 419-425; i) C. A. Smith, M. R. Narouz, P. A. Lummis, I. Singh, A. Nazemi, C.-H. Li. C. M. Crudden, Chem. Rev. 2019, 119 4986-5056.

[3] a) D. Enders, O. Niemeier. A. Henseler, Chem. Rev. 2007, 107 5606-5655; b) N. Marion, S. Díez-González. S. P. Nolan, Angew. Chem. Int. Ed. 2007, 46 2988-3000; c) M. Fèvre, J. Pinaud, Y. Gnanou, J. Vignolle. D. Taton, Chem. Soc. Rev. 2013, 422142-2172; d) D. M. Flanigan, F. Romanov-Michailidis, N. A. White. T. Rovis, Chem. Rev. 2015, 115 9307-9387; e) H. A. Sharma, M. Todd Hovey. K. A. Scheidt, Chem. Commun. 2016, 52 9283-9286; f) K. J. R. Murauski, A. A. Jaworski. K. A Scheidt, Chem. Soc. Rev. 2018, 47 1773-1782; g) Y. Liu, Q. Chen, C. Mou, L. Pan, X. Duan, X. Chen, H. Chen, Y. Zhao, Y. Lu, Z. Jin. Y. R. Chi, Nat. Commun. 2019, 101675 ; h) E. R. Miller, M. T. Hovey. K. A. Scheidt, J. Am. Chem. Soc. 2020, $1422187-2192$.

[4] a) J. M. Farrell, J. A. Hatnean. D. W. Stephan, J. Am. Chem. Soc. 2012, 134 15728-15731; b) C. D. Martin, M. Soleilhavoup. G. Bertrand, Chem. Sci. 2013, 4 3020-3030; c) A. V Zhukhovitskiy, J. Geng. J. A. Johnson, Chem. Eur. J. 2015, 21 5685-5688; d) L. Y. M. Eymann, A. G. Tskhovrebov, A. Sienkiewicz, J. L. Bila, I. Živković, H. M. Rønnow, M. D. Wodrich, L. Vannay, C. Corminboeuf, P. Pattison, E. Solari, R. Scopelliti. K. Severin, J. Am. Chem. Soc. 2016, 13815126 15129; e) J. Back, J. Park, Y. Kim, H. Kang, Y. Kim, M. J. Park, K. Kim. E. Lee, J. Am. Chem. Soc. 2017, 139 1530015303; f) P. W. Antoni. M. M. Hansmann, J. Am. Chem. Soc.
2018, 140 14823-14835; g) M. J. Böhm, C. Golz, I. Rüter. M. Alcarazo, Chem. Eur. J. 2018, 24 15026-15035; h) Y. Kim, K. Kim. E. Lee, Angew. Chem. Int. Ed. 2018, 57262-265; i) P. W Antoni, T. Bruckhoff. M. M. Hansmann, J. Am. Chem. Soc. 2019, 141 9701-9711; j) Y. Kim, C. W. Bielawski. E. Lee, Chem. Commun. 2019, 55 7061-7064.

[5] a) B. Cui, B. L. Zheng, K. He. Q. Y. Zheng, J. Nat. Prod. 2003 $661101-1103$; b) S. M. Weinreb, Nat. Prod. Rep. 2007, 24931 948; c) Z. Jin, Nat. Prod. Rep. 2009, 26 382-445.

[6] a) S. Naureen, F. Chaudhry, M. A. Munawar, M. Ashraf, S. Hamid. M. A. Khan, Bioorg. Chem. 2018, 76 365-369; b) M. V. P. dos Santos Nascimento, A. C. Mattar Munhoz, B. M. De Campos Facchin, E. Fratoni, T. A. Rossa, M. Mandolesi Sá C. C. Campa, E. Ciraolo, E. Hirsch. E. M. Dalmarco, Biomed. Pharmacother. 2019, 111 1399-1407; c) X. Zheng, Z. Ma. D. Zhang, Pharmaceuticals 2020, 1337.

[7] a) K. Hirano, S. Urban, C. Wang. F. Glorius, Org. Lett. 2009, 11 1019-1022; b) T. Lv, Z. Wang, J. You, J. Lan. G. Gao, J. Org. Chem. 2013, 78 5723-5730; c) B. Pooi, J. Lee, K. Choi, H. Hirao. S. H. Hong, J. Org. Chem. 2014, 79 9231-9245; d) D. A. Shabalin. J. E. Camp, Org. Biomol. Chem. 2020, 18 3950 3964.

[8] a) T. Kano, K. Sasaki. K. Maruoka, Org. Lett. 2005, 71347 1349; b) D. Martin, S. Kehrli, M. d'Augustin, H. Clavier, M. Mauduit. A. Alexakis, J. Am. Chem. Soc. 2006, 128 8416-8417; c) D. Baskakov, W. A. Herrmann, E. Herdtweck. S. D. Hoffmann, Organometallics 2007, 26 626-632; d) D. Banerjee, A. K. Buzas, C. Besnard. E. P. Kündig, Organometallics 2012, 31 8348-8354; e) F. Wang, L.-j. Liu, W. Wang, S. Li. M. Shi, Coord. Chem. Rev. 2012, 256 804-853; f) D. Janssen-Müller, C. Schlepphorst. F. Glorius, Chem. Soc. Rev. 2017, 464845 4854; g) J. Diesel, D. Grosheva, S. Kodama. N. Cramer, Angew. Chem. Int. Ed. 2019, 58 11044-11048; h) C. Fliedel, A. Labande, E. Manoury. R. Poli, Coord. Chem. Rev. 2019, 394 $65-103$; i) J. Thongpaen, R. Manguin. O. Baslé, Angew. Chem. Int. Ed. 2020, 59 10242-10251.

[9] a) B. A. B. Prasad. S. R. Gilbertson, Org. Lett. 2009, 113710 3713; b) R. M. Thomas, B. K. Keitz, T. M. Champagne. R. H Grubbs, J. Am. Chem. Soc. 2011, 133 7490-7496; c) J. Tornatzky, A. Kannenberg. S. Blechert, Dalton Trans. 2012, 41 8215-8225; d) P. Queval, C. Jahier, M. Rouen, I. Artur, J.-C Legeay, L. Falivene, L. Toupet, C. Crévisy, L. Cavallo, O. Baslé. M. Mauduit, Angew. Chem. Int. Ed. 2013, 52 14103 14107; e) R. Tarrieu, A. Dumas, J. Thongpaen, T. Vives, T. Roisnel, V. Dorcet, C. Crévisy, O. Baslé. M. Mauduit, J. Org Chem. 2017, 82 1880-1887; f) A. Dumas, R. Tarrieu, T. Vives, T. Roisnel, V. Dorcet, O. Baslé. M. Mauduit, ACS Catal. 2018, $83257-3262$.

[10] a) J. C. C. Chen. I. J. B. Lin, Organometallics 2000, 195113 5121 ; b) H. V. Huynh, C. H. Yeo. G. K. Tan, Chem. Commun 2006, 3833-3835; c) S. A. Mungur, A. J. Blake, C. Wilson, J. McMaster. P. L. Arnold, Organometallics 2006, 25 1861-1867; d) R. Wang, Z. Zeng, B. Twamley, M. M. Piekarski. J. n. M Shreeve, Eur. J. Org. Chem. 2007, 2007655-661; e) C. Fliedel, G. Schnee. P. Braunstein, Dalton Trans. 2009, 2474-2476; f) M. V. Jiménez, J. Fernández-Tornos, J. J. Pérez-Torrente, F. J. Modrego, S. Winterle, C. Cunchillos, F. J. Lahoz. L. A. Oro, Organometallics 2011, 30 5493-5508; g) F. Schroeter, I. Císařová, J. Soellner, E. Herdtweck. T. Strassner, Dalton Trans. 2018, $4716638-16650$.

[11] a) V. Lavallo, Y. Canac, C. Präsang, B. Donnadieu. G. Bertrand, Angew. Chem. Int. Ed. 2005, 44 5705-5709; b) M. Melaimi, R. Jazzar, M. Soleilhavoup. G. Bertrand, Angew. Chem. Int. Ed. 2017, 56 10046-10068; c) U. S. D. Paul. U. Radius, Eur. J. Inorg. Chem. 2017, $20173362-3375$.

[12] C. Goedecke, M. Leibold, U. Siemeling. G. Frenking, J. Am. Chem. Soc. 2011, 133 3557-3569.

[13] a) A. S. Romanov, D. Di, L. Yang, J. Fernandez-Cestau, C. R. Becker, C. E. James, B. Zhu, M. Linnolahti, D. Credgington. M. Bochmann, Chem. Commun. 2016, 52 6379-6382; b) D. Di, A. S. Romanov, L. Yang, J. M. Richter, J. P. H. Rivett, S Jones, T. H. Thomas, M. Abdi Jalebi, R. H. Friend, M. Linnolahti, M. Bochmann. D. Credgington, Science 2017, 356 159-163; c) M. Gernert, U. Müller, M. Haehnel, J. Pflaum. A Steffen, Chem. Eur. J. 2017, 23 2206-2216; d) R. Hamze, R. Jazzar, M. Soleilhavoup, P. I. Djurovich, G. Bertrand. M. E. Thompson, Chem. Commun. 2017, 53 9008-9011; e) A. S. Romanov, C. R. Becker, C. E. James, D. Di, D. Credgington, M. Linnolahti. M. Bochmann, Chem. Eur. J. 2017, 23 4625 
4637; f) R. Hamze, J. L. Peltier, D. Sylvinson, M. Jung, J. Cardenas, R. Haiges, M. Soleilhavoup, R. Jazzar, P. I. Djurovich, G. Bertrand. M. E. Thompson, Science 2019, 363 601-606; g) M. Deng, N. F. M. Mukthar, N. D. Schley. G. Ung, Angew. Chem. Int. Ed. 2020, 59 1228-1231.

[14] a) D. R. Anderson, V. Lavallo, D. J. O'Leary, G. Bertrand. R. H. Grubbs, Angew. Chem. Int. Ed. 2007, 46 7262-7265; b) V. Lavallo, G. D. Frey, B. Donnadieu, M. Soleilhavoup. G. Bertrand, Angew. Chem. Int. Ed. 2008, 47 5224-5228; c) X Zeng, R. Kinjo, B. Donnadieu. G. Bertrand, Angew. Chem. Int Ed. 2010, 49 942-945; d) L. Jin, E. A. Romero, M. Melaimi. G. Bertrand, J. Am. Chem. Soc. 2015, 137 15696-15698; e) V. M. Marx, A. H. Sullivan, M. Melaimi, S. C. Virgil, B. K. Keitz, D S. Weinberger, G. Bertrand. R. H. Grubbs, Angew. Chem. Int Ed. 2015, 54 1919-1923; f) G. Ung. J. C. Peters, Angew. Chem. Int. Ed. 2015, 54 532-535; g) Y. Wei, B. Rao, X. Cong. X. Zeng J. Am. Chem. Soc. 2015, 137 9250-9253; h) D. Butilkov, A Frenklah, I. Rozenberg, S. Kozuch. N. G. Lemcoff, ACS Catal. 2017, 77634-7637; i) M. P. Wiesenfeldt, Z. Nairoukh, W. Li. F. Glorius, Science 2017, 357908-912; j) D. L. Nascimento. D. E. Fogg, J. Am. Chem. Soc. 2019, 141 19236-19240.

[15] a) O. Back, M. A. Celik, G. Frenking, M. Melaimi, B. Donnadieu. G. Bertrand, J. Am. Chem. Soc. 2010, 132 10262-10263; b) O. Back, B. Donnadieu, P. Parameswaran, G. Frenking. G. Bertrand, Nat. Chem. 2010, 2 369-373; c) J. K. Mahoney, D. Martin, C. E. Moore, A. L. Rheingold. G. Bertrand, J. Am. Chem. Soc. 2013, 135 18766-18769; d) K. C. Mondal, H. W. Roesky, A. C. Stückl, F. Ehret, W. Kaim, B. Dittrich, B. Maity. D. Koley, Angew. Chem. Int. Ed. 2013, $5211804-11807$; e) P. Bissinger, H. Braunschweig, A. Damme, I. Krummenacher, A. K. Phukan, K. Radacki. S. Sugawara, Angew. Chem. Int. Ed. 2014, 53 7360-7363; f) K. C. Mondal, B. Dittrich, B. Maity, D. Koley. H. W. Roesky, J. Am. Chem. Soc. 2014, 136 9568-9571; g) J. K Mahoney, D. Martin, F. Thomas, C. E. Moore, A. L. Rheingold. G. Bertrand, J. Am. Chem. Soc. 2015, 1377519-7525; h) L. Gu Y. Zheng, E. Haldón, R. Goddard, E. Bill, W. Thiel. M. Alcarazo, Angew. Chem. Int. Ed. 2017, 56 8790-8794; i) K. M. Melancon, M. B. Gildner. T. W. Hudnall, Chem. Eur. J. 2018, 24 9264-9268; j) J. Messelberger, A Grünwald, P. Pinter, M. M. Hansmann. D. Munz, Chem. Sci. 2018, 9 6107-6117; k) S Kundu, S. Sinhababu, V. Chandrasekhar. H. W. Roesky, Chem. Sci. 2019, 10 4727-4741; I) J. Messelberger, A Grünwald, S. J. Goodner, F. Zeilinger, P. Pinter, M. E. Miehlich, F. W. Heinemann, M. M. Hansmann. D. Munz, Chem. Sci. 2020, 11 4138-4149; m) T. Ullrich, P. Pinter, J. Messelberger, P. Haines, R. Kaur, M. M. Hansmann, D. Munz. D. M. Guldi, Angew. Chem. Int. Ed. 2020, 59 7906-7914.

[16] a) V. Lavallo, Y. Canac, B. Donnadieu, W. W. Schoeller. G. Bertrand, Angew. Chem. Int. Ed. 2006, 45 3488-3491; b) G. D. Frey, V. Lavallo, B. Donnadieu, W. W. Schoeller. G. Bertrand, Science 2007, 316 439; c) D. Martin, M. Soleilhavoup. G. Bertrand, Chem. Sci. 2011, 2 389-399; d) Z. R. Turner. J.-C Buffet, Dalton Trans. 2015, 44 12985-12989; e) C. Mohapatra P. P. Samuel, B. Li, B. Niepötter, C. J. Schürmann, R. HerbstIrmer, D. Stalke, B. Maity, D. Koley. H. W. Roesky, Inorg Chem. 2016, 55 1953-1955; f) H. Song, Y. Kim, J. Park, K. Kim. E. Lee, Synlett 2016, 27 477-485; g) Z. R. Turner, Chem. Eur. J. 2016, 22 11461-11468; h) S. Würtemberger-Pietsch, H. Schneider, T. B. Marder. U. Radius, Chem. Eur. J. 2016, 22 13032-13036; i) U. S. D. Paul. U. Radius, Chem. Eur. J. 2017, 23 3993-4009

[17] a) T. W. Hudnall. C. W. Bielawski, J Am Chem Soc 2009, 131 16039-16041; b) M. Braun, W. Frank, G. J. Reiss. C. Ganter, Organometallics 2010, 29 4418-4420; c) D. Martin, N Lassauque, B. Donnadieu. G. Bertrand, Angew. Chem. Int. Ed. 2012, 51 6172-6175; d) M. J. López-Gómez, D. Martin. G. Bertrand, Chem. Commun. 2013, 49 4483-4485; e) B. Rao, H. Tang, X. Zeng, L. Liu, M. Melaimi. G. Bertrand, Angew. Chem Int. Ed. 2015, 54 14915-14919; f) Z. R. McCarty, D. N Lastovickova. C. W. Bielawski, Chem. Commun. 2016, 52 5447-5450; g) E. Tomás-Mendivil, M. M. Hansmann, C. M. Weinstein, R. Jazzar, M. Melaimi. G. Bertrand, J. Am. Chem. Soc. 2017, 1397753-7756; h) H. Song, H. Kim. E. Lee, Angew. Chem. Int. Ed. 2018, 57 8603-8607; i) C. M. Weinstein, G. P Junor, D. R. Tolentino, R. Jazzar, M. Melaimi. G. Bertrand, J. Am. Chem. Soc. 2018, 140 9255-9260; j) M. B. Gildner. T. W Hudnall, Chem. Commun. 2019, 55 12300-12303; k) P. R. Sultane, G. Ahumada, D. Janssen-Müller. C. W. Bielawski, Angew. Chem. Int. Ed. 2019, 58 16320-16325.
[18] a) D. W. Armstrong, Y.-S. Liu, L. He, K. H. Ekborg-Ott, C. L. Barnes. C. F. Hammer, J. Agric. Food. Chem. 2002, $50473-$ 476; b) N. Gathergood. P. J. Scammells, Org. Lett. 2003, 5921 923; c) T. V. Sravanthi. S. L. Manju, Eur. J. Pharm. Sci. 2016 $911-10$.

[19] a) G. R. Humphrey. J. T. Kuethe, Chem. Rev. 2006, $1062875-$ 2911; b) Y.-D. Shao. S.-K. Tian, Chem. Commun. 2012, 48 4899-4901; c) A. Lin, J. Yang. M. Hashim, Org. Lett. 2013, 15 1950-1953; d) P. Fedoseev. E. Van der Eycken, Chem. Commun. 2017, 53 7732-7735; e) J. T. R. Liddon, J. A. RossiAshton, R. J. K. Taylor. W. P. Unsworth, Org. Lett. 2018, 20 3349-3353; f) G. Bai, F. Dong, L. Xu, Y. Liu, L. Wang. S.-S. Li, Org. Lett. 2019, 21 6225-6230.

[20] a) C. Michon, F. Medina, M.-A. Abadie. F. AgbossouNiedercorn, Organometallics 2013, 32 5589-5600; b) H Sivaram, J. Tan. H. V. Huynh, Dalton Trans. 2013, 4212421 12428; c) B. Yiğit, Y. Işık, D. Barut Celepci, E. Evren, M. Yiğit, N. Gürbüz. İ. Özdemir, Inorg. Chim. Acta 2020, 499119199.

[21] G. Bertrand, G. Junor, J. Lorkowski, C. Weinstein, R. Jazzar. C. Pietraszuk, Angew. Chem. Int. Ed. n/a.

[22] a) A. Liske, K. Verlinden, H. Buhl, K. Schaper. C. Ganter Organometallics 2013, 32 5269-5272; b) K. Verlinden, H. Buhl, W. Frank. C. Ganter, Eur. J. Inorg. Chem. 2015, 20152416 2425.

[23] S. V. C. Vummaleti, D. J. Nelson, A. Poater, A. Gómez-Suárez, D. B. Cordes, A. M. Z. Slawin, S. P. Nolan. L. Cavallo, Chem Sci. 2015, 6 1895-1904.

[24] a) S. Dierick, D. F. Dewez. I. E. Markó, Organometallics 2014, 33 677-683; b) X. Hu, M. Soleilhavoup, M. Melaimi, J. Chu. G. Bertrand, Angew. Chem. Int. Ed. 2015, $546008-6011$; c) Y. Kim, Y. Kim, M. Y. Hur. E. Lee, J. Organomet. Chem. 2016, 8201 7 .

[25] Z. Wen, Y. Zhang, S. Roland. M. Sollogoub, Eur. J. Org. Chem. 2019, 2019 2682-2687.

[26] T. Itoh, Y. Shimizu. M. Kanai, J. Am. Chem. Soc. 2016, 138 7528-7531. 